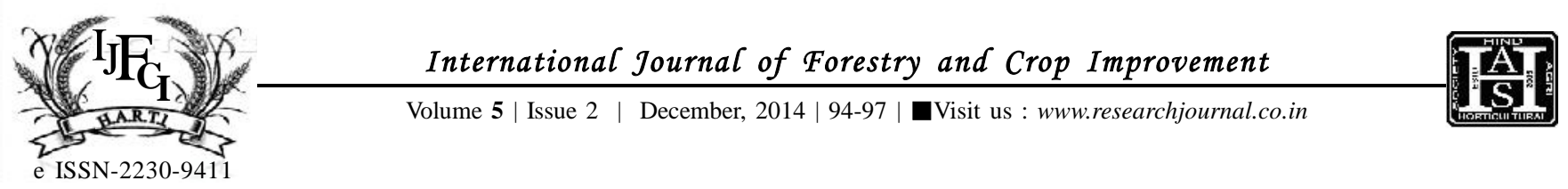

\title{
Mollitrichosiphum spp: A new record of aphid from Alder-large cardamom ecosystem in Sikkim
}

\author{
T. N. DEKA, B. A. GUDADE, A.K. ViJAYAN AND P. CHHETRI
}

\begin{abstract}
Aphids (Hemiptera: Apihidoidea) pest problems were well known worldwide. A total 823 species in 222 genera and 18 sub families of the family Aphididae were known from the Indian sub continent. In Eastern Himalayas and North East India, 464 species in 147 genera in 15 sub families of aphids were known to be available. Sikkim belonged to NE India. From Sikkim, 26 important $A p h i d s$ were reported so far. Three species of aphids were known to be associated with Alder (Alnus nepalensis) in North East India. Large cardamom (Amomum subulatum Roxb.) was an important cash crop of Eastern Himalayan region. It was sciophytes i.e., the plant grew under shade. The crop grew somewhat wild in nature and damage due to insect pests was common. It was infested by various pests and diseases causing considerable amount of monetary loss. Surveillance was conducted in alder - large cardamom ecosystem in four different districts of Sikkim during 2011 to 2013. Mollitrichosiphum spp reported for the first time from Sikkim region. An observation about aphid species associated with alder tree in large cardamom ecosystem in Sikkim was presented.
\end{abstract}

KEY WORDS : Alnus nepalensis, Aphis spp., Large cardamom, Mollitrichosiphum spp., Sikkim

How to cite this Article : Deka, T.N., Gudade, B.A., Vijayan, A.K. and Chhetri, P. (2014). Mollitrichosiphum spp: A new record of aphid from Alder-large cardamom ecosystem in Sikkim. Internat. J. Forestry \& Crop Improv., 5 (2) : 94-97.

Article Chronical : Received : 04.11.2014; Accepted : 28.11.2014

\section{MEMBERS OF RESEARCH FORUM}

Address of the Correspondence :

B.A. GUDADE, Department of Agronomy, Indian Cardamom Research Institute, Regional Research Station, Spices Board, Tadong, GANGTOK (SIKKIM) INDIA

Email: bgudade@gmail.com

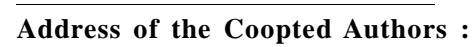

T.N. DEKA, Department of Entomology, Indian Cardamom Research Institute, Regional Research Station, Spices Board, Tadong, GANGTOK (SIKKIM) INDIA

Email: tikendrandeka@gmail.com

A.K. VIJAYAN, Department of Plant Pathology, Indian Cardamom Research Institute, Regional Research Station, Spices Board, Tadong, GANGTOK (SIKKIM) INDIA

drvijayannambiar@gmail.com

P. CHHETRI, Department of Crop Botany, Indian Cardamom Research Institute, Regional Research Station, Spices Board, Tadong, GANGTOK (SIKKIM) INDIA

prashantchhetri24@yahoo.in 